\title{
Human Resource Management Practices in the Hotel Industry in Sri Lanka
}

\author{
Shamil, M. M. M.* \\ Samarakoon, S. M. A. K.* \\ * Dept. of Commerce \& Financial Management, University of Kelaniya
}

\begin{abstract}
Human Resource Management as a discipline has been in existence for decades. However researchers have continued investigating various HRM practices and whether these practices are influenced by various demographic factors pertaining to industries and organizations. Researchers of this study are in pursuit of identifying HRM practices in the hotel industry in Sri Lanka in relation to demographic factors such as ownership of hotel and type of hotels. For the purpose of this study, ownership is defined as whether the hotel is owned by a foreign investor or domestic investor. Type of hotel is defined as whether the hotel belongs to a hotel chain or an independent hotel. The set of HRM practices of hotels was identified using the list of HRM practices prepared by Hoque for his research on HRM practices and performance of hotel in UK. Hoque's list of HRM practices covers eight areas of HRM practices and each area comprises of several HRM practices belonging to that particular area of HRM. Seventy six hotels responded to the questionnaire belonging to six tourist destinations in Sri Lanka. Overall there are 25 HRM practices in the list. Based on finding, it was concluded that there is a significant relationship between the type of hotel and HRM practices.
\end{abstract}

Keywords: HRM Practices, Hotel Industry, Tourism, Ownership, Type of Hotel

\section{Introduction}

The concept of Human Resource Management (HRM) emerged in the early 1980s and continues to evolve as a separate field of study. Extant literature suggest that (Beer et al. 1985) Harvard University and (Fombrun et al. 1984) Michigan University contributed to the initial frameworks on HRM (Truss et al. 1997). According to Schneider and Bowen (1993) effective utilization of human resources provide a competitive edge for organizations (Chand $\&$ Katou 2007). Thus, human resource management practices are an important component of the process of HRM and is important to investigate the adoption of human resource 
management practices in service industry. Since, service industry is mainly driven by efficiency and effectiveness of employees in organizations.

Current HRM literature identifies significant and positive relationship between human resource management and organizational performance. Therefore, managing human resources in an organization is very important towards achieving organizational goals and objectives. The hotel industry is necessarily labour intensive and this makes HRM practices particularly important and it should develop effective human resource practices and policies to achieve competitive success (Alleyne et al. 2006). Research on HRM practices in the Service sector industries are relatively few and the hotel sector is a major segment of service industry (Collier \& Gregory, 1995). According to Hoque (1999, p. 420) the hotel industry has typically reported poor practices and a lack of interest in HRM among managers“. However interest in HRM within the hotel industry has significantly increased over the years and heterogeneity in the service sector is identified as an obstacle to investigate the sector as whole (Hoque, 1999; Chand \& Katou 2007).

\section{Tourism and Hotel Industry in Sri Lanka}

Tourism is the fourth largest foreign exchange earner in Sri Lanka ${ }^{[7]}$. In the year 2007 tourism earned US \$ 384.4 million as foreign exchange, and this was a contribution of $3.1 \%$ to the total foreign exchange earnings in Sri Lanka (Sri Lanka Tourism Development Authority, 2007). Employment generation in the tourism sector grew by $8.7 \%$ in 2007 . This emphasis that the Sri Lankan hotel industry has continued to grow and has a significant role in the economy. Therefore, examining the hotel industry in Sri Lanka is significant in current context. Furthermore, HRM is relatively new to Sri Lankan organizations and there is little information on how Sri Lankan organizations are embedding HRM. Hence exploring HRM practices in hotels in Sri Lanka would provide insights on how HRM is shaping these organizations.

Previous studies in hotel industries have examined whether HRM practices are significantly influenced by ownership of hotel or type of hotel. The study conducted by Timo and Davidson (2005) compared HRM practices in Australian hotels based on type of ownership: whether hotels are MNCs or domestically owned. In their study, the domestically owned hotels were very few but yet the researchers found significant differences of HRM practices based on the ownership. Further the study conducted by Chand and Katou (2007) used type of hotel: chain or independent as a variable. Despite of lack of literature literature on hotel 
industry ownership and types of hotel in Sri Lanka, it is observable that these two factors are important determinants to investigate.

\section{Statement of the Problem}

It's generally agreed that contemporary management literature as well as concepts have emerged in post industrial revolution era where manufacturing industry continued to be the soul of economies and this led to the emergence of research in an industrial setting. Post World War II, services industries continued to expand and economies have experienced transformation from a traditional industrial setting to an emerging service industry landscape.

Hospitality industry is considered a sub category within the services industry and has experienced significant growth with expanding global economy and positive changes pertaining to travel and hospitality industry in global environment. Further, services industry is widely accepted to be driven by customer satisfaction and therefore human resources are essential component of service delivery. Therefore investigating HRM practices in a labour intensive industry such as hotel is important.

Studies conducted by Hoque (1999), Alleyne et al. (2006) and Chand and Katou (2007) have examined HRM practices in hotel industry in UK, Barbados and India respectively. Although the studies have been conducted in different years and there is a significant gap between the studies, comparison of HRM practices in these studies provide significant insights on the adoption of HR practices in three countries.

Based on the findings of the above studies it can be stated that HRM in the hotel industry is widely adopted and researches are emerging from developed and emerging markets examining HRM practices. Therefore, this study focuses on identifying HRM practices in the Hotel industry in Sri Lanka and whether there is a significant difference in HRM practices in chain hotels and indpendent hotels.

\section{Methodology}

A questionnaire was designed to collect data from hotels. The questionnaire is constituted of hotel profile, HR department profile, and HR practices. Hotel profile section of the questionnaire includes questions related to demography of the hotels. The HR department profile section of the questionnaire include questions on size of the HR department, job designation of HR personnel, qualifications and experience of the HR personnel. HR practices section of the questionnaire includes questions on HR practices as used in the study 
conducted in UK hotel industry [6]. The same questionnaire was also adopted in the study conducted in Barbados [1].

The tourist regions in Sri Lanka are categorized into six (06) major areas. They are Colombo City, Greater Colombo, South Coast, East Coast, High Country and Ancient Cities. Based on accommodation capacity, South Coast has the highest accommodation capacity followed by Colombo City, Greater Colombo, and Ancient Cities. Accommodation capacity in Up Country and East Coast is very low compared to other tourist regions in the country. According to Sri Lanka Tourism Development Authority (2007) there were 245 hotels in the six major tourist areas. A sample of hundred (100) hotels were selected using stratified random sampling method. Seventy six (76) hotels responded to the questionnaire on HRM practices. Out of the 76 questionnaires received one (01) of the questionnaire was removed as it was incomplete. Hence a total of seventy five (75) questionnaires were used for the analysis.

\section{Data Analysis and Discussion}

Initial discussion of the analysis provides an overview on background data pertaining to the study. As mentioned earlier, tourism regions are categorized into 6 major destinations, in Sri Lanka. Table 1 classifies the respondents (hotels) according to these regions.

Table 1: Regions of Respondent Hotels

\begin{tabular}{|l|c|c|}
\hline \multicolumn{1}{|c|}{ Region } & Frequency & Percent \\
\hline Colombo City & 6 & 8.0 \\
Greater Colombo & 11 & 14.7 \\
South Coast & 31 & 41.3 \\
High Country & 5 & 6.7 \\
Ancient Cities & 18 & 24.0 \\
Eastern Coast & 2 & 2.7 \\
Other & 2 & 2.7 \\
Total & $\mathbf{7 5}$ & $\mathbf{1 0 0 . 0}$ \\
\hline
\end{tabular}

Majority (41.3\%) of the hotels responded to the survey comes from South Coast. The second most respondents comes from Ancient cities which is $24 \%$. Respondents from Colombo city and Greater Colombo area are $14.7 \%$ and $8 \%$ respectively. Rest of the respondents comes from other destinations. 
Table 2: Hotel Ownership

\begin{tabular}{|l|c|c|}
\hline Ownership & Frequency & Percent \\
\hline Domestic & 64 & 85.3 \\
Foreign & 11 & 14.7 \\
Total & $\mathbf{7 5}$ & $\mathbf{1 0 0 . 0}$ \\
\hline
\end{tabular}

According to data on hotel ownership provided in Table 2, it can be stated that $85.3 \%$ of the hotels responded to the questionnaire were domestically owned hotels and $14.7 \%$ were hotels with foreign ownership. Table 3 provides details on type of hotel. Based on the findings, it is identified that $58 \%$ of the hotels responded were belonging to the chain hotel type whereas the balance $42 \%$ belongs to the independent hotel type.

Table 3: Type of Hotel

\begin{tabular}{|l|c|c|}
\hline Type of Hotel & Frequency & Percent \\
\hline Chain & 44 & 58.7 \\
Independent & 31 & 41.3 \\
Total & $\mathbf{7 5}$ & $\mathbf{1 0 0 . 0}$ \\
\hline
\end{tabular}

The study employed a questionnaire developed by Hoque and has been used in UK, Barbados and in India. Hence there is evidence to support reliability of the questionnaire. However the authors performed a reliability test for the questionnaire and found Cronbach Alpha a value of 0.863 which is higher than the required 0.70 (Hair et al. 1998).

Table 4: Reliability Analysis

\begin{tabular}{|c|c|}
\hline Cronbachs Alpha & No. of Items \\
\hline .863 & 25 \\
\hline
\end{tabular}

As the data in the study categorical in nature, Spearman correlation was performed to identify any association between hotel type and HRM practices.

Table 5: Spearman Correlation Results

\begin{tabular}{|l|c|c|}
\hline \multicolumn{1}{|c|}{ HRM Practices } & Ownership & $\begin{array}{c}\text { Type of } \\
\text { Hotel }\end{array}$ \\
\hline $\begin{array}{l}\text { Harmonized terms and conditions between management and } \\
\text { non-management staff }\end{array}$ & $.109(.353)$ & $-.140(.230)$ \\
\hline Single status for all staff & $.150(.199)$ & $.045(.703)$ \\
\hline
\end{tabular}




\begin{tabular}{|c|c|c|}
\hline $\begin{array}{l}\text { Internal promotion the norm for appointments above the basic } \\
\text { levels }\end{array}$ & $.152(.194$ & $-.040(.734)$ \\
\hline No compulsory redundancy & $\begin{array}{l}-.061 \\
(.603)\end{array}$ & $-.062(.595)$ \\
\hline Trainability as a major selection criterion & $.172(.142)$ & $-.219(.059)$ \\
\hline $\begin{array}{l}\text { Use of psychological tests as the norm for the selection of all } \\
\text { staff }\end{array}$ & $\begin{array}{l}-.162 \\
(.166)\end{array}$ & $.105(.370)$ \\
\hline $\begin{array}{l}\text { Multi Skilling \& Experience as criteria for the selection of all } \\
\text { staff }\end{array}$ & $\begin{array}{l}-.079 \\
(.501)\end{array}$ & $-.073(.531)$ \\
\hline $\begin{array}{l}\text { Deliberate use of realistic job previews during recruitment and } \\
\text { selection }\end{array}$ & $.235(.042)$ & $-.098(.405)$ \\
\hline $\begin{array}{l}\text { A formal system for communicating the values and systems in } \\
\text { the company to new staff }\end{array}$ & $.129(.272)$ & $-.069(.559)$ \\
\hline Formal HR planning & $.169(.148)$ & $-.136(.244)$ \\
\hline Career planning & $.306(.008)$ & $-.143(.222)$ \\
\hline Formal training \& development & $.190(.103)$ & $.005(.965)$ \\
\hline Deliberate development of a learning organization & $.210(.071)$ & $-.138(.236)$ \\
\hline $\begin{array}{l}\text { An explicit policy requiring all staff to spend a specified } \\
\text { minimum period annually in formal training }\end{array}$ & $.135(.249)$ & $-.157(.178)$ \\
\hline Flexible job descriptions that are not linked to one specific task & $.122(.298)$ & $-.032(.783)$ \\
\hline $\begin{array}{l}\text { Deliberate design of jobs to make full use of workers' skills and } \\
\text { abilities } \\
\text { (i.e. use of job enrichment and/or autonomous work groups) }\end{array}$ & $.249(.031)$ & $-.081(.491)$ \\
\hline Work organized around team working for the majority of staff & $.154(.186)$ & $.016(.892)$ \\
\hline Staff involvement in setting performance targets/objectives & $\begin{array}{l}-.101 \\
(.389)\end{array}$ & $.197(.091)$ \\
\hline Production/service staff responsible for their own quality & $.070(.549)$ & $.002(.985)$ \\
\hline $\begin{array}{l}\text { A majority of workers currently involved in quality circles or } \\
\text { quality improvement teams }\end{array}$ & $.178(.126)$ & $.038(.746)$ \\
\hline Regular use of attitude surveys to obtain the views of staff & $.214(.065)$ & $.064(.583)$ \\
\hline $\begin{array}{l}\text { A system of regular, planned team briefing or cascade of } \\
\text { information from senior management to the lower grades/shop } \\
\text { floor during which work stops }\end{array}$ & $.217(.062)$ & $-.042(.718)$ \\
\hline
\end{tabular}




\begin{tabular}{|l|c|c|}
\hline $\begin{array}{l}\text { All staff are informed about the market position, competitive } \\
\text { pressures and establishment and company performance as a } \\
\text { matter of course }\end{array}$ & $.101(.387)$ & $-.089(.450)$ \\
\hline A merit element in the pay of staff at all levels & $.149(.201)$ & $.027(.819)$ \\
\hline Formal appraisal of all staff on a regular basis at least annually & $.109(.350)$ & $-.112(.337)$ \\
\hline
\end{tabular}

Further, Table 6 provides data on the mean and significance (p) levels on HRM practices in chain hotels and independent hotels. The authors further conducted the t-Test to determine whether HRM practices in chain hotels are significantly different from independnt hotels. However there was no evidence to reject the hypothesis that HRM practices in chain hotels and independent hotels are different. (See Appendix for t-Test results).

\section{Table 6: HRM Practices}

\begin{tabular}{|l|c|c|}
\hline & Chain & Independent \\
\hline Harmonized terms and conditions between management & 2.6136 & 2.4516 \\
and non-management staff & $(.49254)$ & $(.56796)$ \\
\hline Single status for all staff & 2.1818 & 2.2581 \\
\hline Internal promotion the norm for appointments above the & 2.5227 & 2.4516 \\
basic levels & $(.59018)$ & $(.67521)$ \\
\hline & 2.0682 & 1.9677 \\
No compulsory redundancy & $(.81833)$ & $(.79515)$ \\
\hline Trainability as a major selection criterion & 2.5455 & 2.2903 \\
& $(.54792)$ & $(.58842)$ \\
\hline Use of psychological tests as the norm for the selection & 1.5682 & 1.7097 \\
of all staff & $(.72810)$ & $(.73908)$ \\
\hline Multi Skilling \& Experience as criteria for the selection & 2.4773 & 2.3548 \\
of all staff & $(.59018)$ & $(.70938)$ \\
\hline Deliberate use of realistic job previews during & 2.2955 & 2.1935 \\
recruitment and selection & $(.73388)$ & $(.60107)$ \\
\hline A formal system for communicating the values and & 2.5682 & 2.4839 \\
systems in the company to new staff & $(.58658)$ & $(.62562)$ \\
\hline Formal HR planning & 2.3636 & 2.1935 \\
& $(.68509)$ & $(.65418)$ \\
\hline
\end{tabular}




\begin{tabular}{|c|c|c|}
\hline Career planning & $\begin{array}{l}2.3409 \\
(.64495)\end{array}$ & $\begin{array}{l}2.1613 \\
(.63754)\end{array}$ \\
\hline Formal training \& development & $\begin{array}{c}2.5227 \\
(.66433)\end{array}$ & $\begin{array}{r}2.5806 \\
(.50161)\end{array}$ \\
\hline Deliberate development of a learning organization & $\begin{array}{c}2.2727 \\
(.75832)\end{array}$ & $\begin{array}{l}2.0968 \\
(.65089)\end{array}$ \\
\hline $\begin{array}{l}\text { An explicit policy requiring all staff to spend a specified } \\
\text { minimum period annually in formal training }\end{array}$ & $\begin{array}{c}2.2045 \\
(.73388)\end{array}$ & $\begin{array}{c}1.9677 \\
(.75206)\end{array}$ \\
\hline $\begin{array}{l}\text { Flexible job descriptions that are not linked to one } \\
\text { specific task }\end{array}$ & $\begin{array}{l}2.2500 \\
(.75097)\end{array}$ & $\begin{array}{l}2.1935 \\
(.79244)\end{array}$ \\
\hline $\begin{array}{l}\text { Deliberate design of jobs to make full use of } \\
\text { workers'skills and abilities (i.e. use of job enrichment } \\
\text { and/or autonomous work groups) }\end{array}$ & $\begin{array}{c}2.5909 \\
(.49735)\end{array}$ & $\begin{array}{c}2.4516 \\
(.67521)\end{array}$ \\
\hline $\begin{array}{l}\text { Work organized around team working for the majority of } \\
\text { staff }\end{array}$ & $\begin{array}{l}2.6818 \\
(.51817)\end{array}$ & $\begin{array}{r}2.6452 \\
(.66073)\end{array}$ \\
\hline $\begin{array}{l}\text { Staff involvement in setting performance } \\
\text { targets/objectives }\end{array}$ & $\begin{array}{c}2.2045 \\
(.82348)\end{array}$ & $\begin{array}{c}2.5161 \\
(.72438)\end{array}$ \\
\hline Production/service staff responsible for their own quality & $\begin{array}{r}2.6136 \\
(.57933)\end{array}$ & $\begin{array}{l}2.6452 \\
(.48637)\end{array}$ \\
\hline $\begin{array}{l}\text { A majority of workers currently involved in quality } \\
\text { circles or quality improvement teams }\end{array}$ & $\begin{array}{l}2.0682 \\
(.84627)\end{array}$ & $\begin{array}{l}2.1290 \\
(.88476)\end{array}$ \\
\hline $\begin{array}{l}\text { Regular use of attitude surveys to obtain the views of } \\
\text { staff }\end{array}$ & $\begin{array}{l}2.2727 \\
(.69428)\end{array}$ & $\begin{array}{l}2.3548 \\
(.70938)\end{array}$ \\
\hline $\begin{array}{l}\text { A system of regular, planned team briefing or cascade of } \\
\text { information from senior management to the lower } \\
\text { grades/shopfloor during which work stops }\end{array}$ & $\begin{array}{c}2.4773 \\
(.69846)\end{array}$ & $\begin{array}{l}2.4194 \\
(.71992)\end{array}$ \\
\hline $\begin{array}{l}\text { All staff are informed about the market position, } \\
\text { competitive pressures and establishment and company } \\
\text { performance as a matter of course }\end{array}$ & $\begin{array}{c}2.5227 \\
(.69846)\end{array}$ & $\begin{array}{l}2.3548 \\
(.83859)\end{array}$ \\
\hline A merit element in the pay of staff at all levels & $\begin{array}{c}2.6818 \\
(.60127)\end{array}$ & $\begin{array}{r}2.7097 \\
(.58842)\end{array}$ \\
\hline $\begin{array}{l}\text { Formal appraisal of all staff on a regular basis at least } \\
\text { annually }\end{array}$ & $\begin{array}{l}2.7045 \\
(.55320)\end{array}$ & $\begin{array}{l}2.5806 \\
(.62044)\end{array}$ \\
\hline
\end{tabular}




\section{Conclusion}

Tourism industry is the fourth highest forex earner for Sri Lanka and its contribution to economy is significant. Because hotel industry plays a pivotal role in a emerging economy in Sri Lanka it is important in engaging research that support and facilitate continued growth of the industry from different disciplines. Based on above premise, this study investigated whether there is a significant difference of HRM practices in relation to ownership of hotel and type of hotel in Sri Lanka. A questionnaire which was previously used to examine HRM practices in hotel industry was utilized for the study. Seventy six hotels out of hundred selected hotels responded to the questionnaire. T-tests were employed to examine whether ownership and type of hotel influenced differences in HRM practices. Based on findings, it can be concluded that HRM practices are not significantly different based on ownership of hotel or type of hotel.

\section{References}

Alleyne, P., Doherty, L., \& Greenidge, D. (2006). Approaches to HRM in the Barbados hotel industry. International Journal of Contemporary Hospitality Management, 18(2), 94 - 109.

Beer, M., Spector, B., Lawrence, P., Mills, D. \& Walton, R. (1985). Human resources management: A general manager's perspective. New York, Free Press.

Chand, M., \& Katou, A. A. (2007). The impact of HRM practices on organizational performance in the Indian hotel industry. Employee Relations, 29( 6), 576 - 594.

Collier, P., \& Gregory, A. (1995). Strategic management accounting: a UK hotel sector case study. International Journal of Contemporary Hospitality Management, 7(1), 16 - 21.

Crick, P. A. (2008). No plantation work here: contemporary HR practices in Caribbean hotels. International Journal of Contemporary Hospitality Management, 20(1), 79 - 89.

Edgar, F., \& Geare, A. (2005). HRM practice and employee attitudes: Different measures different results. Personnel Review, 34(5), 534 - 549.

Formbrun, C., Tichy, N. M., \& Devana, M. A. (1984). Human Resource Management. New York Wiley.

Hair,J. F., Anderson, R. E. J., Tathem, R. L., \& Black,W. C. (1998). Multivariate data analysis. $5^{\text {th }}$ ed, Prentice hall, New Jersery. 
Hoque, K. (1999). Human resource management and performance in the UK hotel industry. British Journal of Industrial Relations, 37(3), 419 - 443.

Schneider, B. \& Bowen, D. E. (1993). The service organisation: human resource management is crucial. Organizational Dynamics, 21(4), 39-52.

Sri Lanka Tourism Development Authority. (2007). Annual Statistical Report of Sri Lanka Tourism. Colombo: Sri Lanka Tourism Development Authority.

Timo, N., \& Davidson, M. (2005). A survey of employee relations practices and demographics of MNC chain and domestic luxury hotels in Australia. Employee Relations, 27(2), $175-192$.

Truss, C., Gratton, L., Hailey, V. H., Mcgovern, P., \& Stiles, P. (1997). Soft and hard models of human resource management: A reappraisal. Journal of Management Studies, 34(1), 53 73. 


\section{Appendix: T-Test Results}

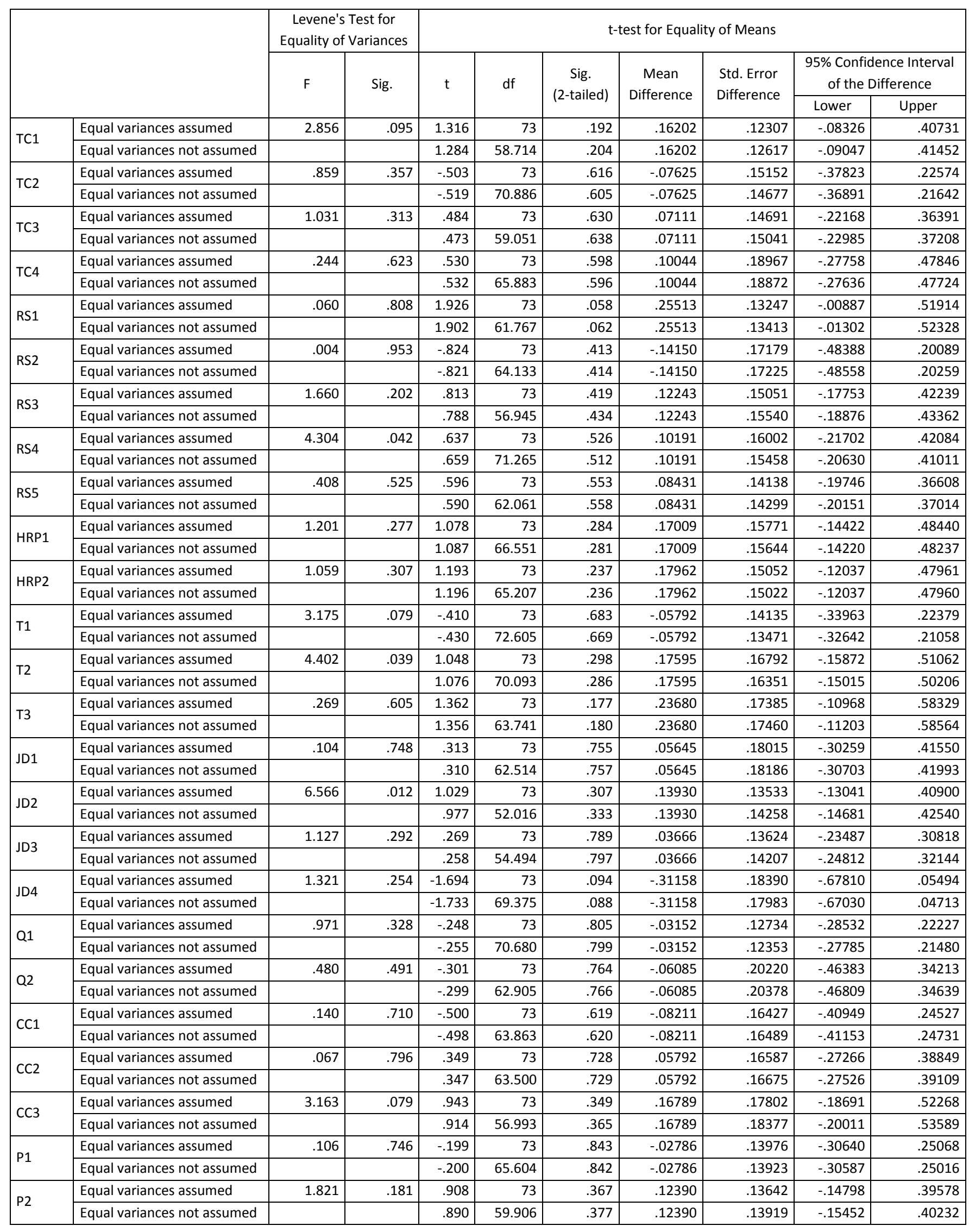

